Gynecologic and

Obstetric Investigation
Gynecol Obstet Invest 2009;68:19-32

DOI: $\underline{10.1159 / 000209675}$
Received: December 28, 2007

Accepted after revision: November 27, 2008

Published online: March 27, 2009

\title{
Towards Fibroid Gene Therapy: Adenovirus- Mediated Delivery of Herpes Simplex Virus 1 Thymidine Kinase Gene/Ganciclovir Shrinks Uterine Leiomyoma in the Eker Rat Model
}

\author{
Memy Hassan ${ }^{\text {a,d }}$ Dong Zhang ${ }^{a, c}$ Salama Salama ${ }^{a, d}$ Farid Hamadad $^{d}$ \\ Hossam Arafa $^{d}$ Hala Fouad $^{a}$ Cheryl Walker $^{b}$ Ayman Al-Hendy ${ }^{a, c}$ \\ aDepartment of Obstetrics and Gynecology, University of Texas Medical Branch, Galveston, Tex., \\ ${ }^{b}$ M.D. Anderson Cancer Center, University of Texas, Smithville, Tex., and 'Department of Obstetrics and \\ Gynecology, Meharry Medical College, Nashville, Tenn., USA; ${ }^{d}$ Department of Pharmacology and Toxicology, \\ Faculty of Pharmacy, Al-Azhar University, Cairo, Egypt
}

\section{Key Words}

Leiomyoma · Gene therapy · HSV1TK/GCV • Eker rat

\begin{abstract}
Background/Aims: The objective of this study was to assess in vivo gene therapy of uterine leiomyomas in the Eker rat model using adenovirus (Ad)-mediated delivery of herpes simplex virus 1 thymidine kinase gene (HSV1TK) followed by ganciclovir (GCV) treatment. Methods: We randomized 27 female Eker rats with MRI-confirmed uterine leiomyomas to a single treatment with direct intra-tumor injection of AdHSV1TK/GCV, Ad-LacZ/GCV, or medium alone. Samples were collected from tumors, other body organs, and blood at 10, 20 , and 30 days after treatment to assess the safety and efficacy of the treatment. Results: Ad-HSV1TK/GCV treatment significantly decreased uterine fibroid volume by $75 \pm 16$, $58.7 \pm 6.3$, and $67.5 \pm 27.5 \%$, of the pretreatment volume at days 10, 20, and 30, respectively. Ad-HSV1TK/GCV increased caspase-3 activity, Bax expression, and TUNEL apoptosis marker, and it decreased cyclin D1, PCNA, Bcl2, and PARP protein expressions. Ad transfection induced local CD4+ and CD8+ infiltration and serum anti-Ad antibodies. Additionally, Ad transfection was tumor-localized and safe to non-tar-
\end{abstract}

get tissues. Conclusion: These studies demonstrate a marked efficiency and high safety for the Ad-HSV1TK/GCV therapeutic approach in the context of Eker rat uterine leiomyomas and provide essential preclinical data for the development of Ad-HSV1TK/GCV gene therapy for uterine fibroids.

Copyright $\odot 2009$ S. Karger AG, Basel

\section{Introduction}

Uterine leiomyomas are the most common female pelvic tumors and occur in 20-25\% of premenopausal women [1]. They commonly cause severe symptoms such as heavy, irregular, and prolonged menstrual bleeding; anemia; pelvic discomfort; bowel and bladder dysfunction; infertility, and recurrent abortion [2-4]. These clinical complications seriously impact women's health.

Currently, only a few treatment options are available to women with symptomatic fibroids [5, 6]. Hysterectomy has been the mainstay for fibroid treatment [7]. This surgical approach is costly, and it carries the additional risks of major morbidity and possible mortality.

Unfortunately, gonadotropin-releasing hormone (Gn$\mathrm{RH}$ ) agonists, an effective nonsurgical treatment option,

\section{KARGER}

Fax +4161306 1234 E-Mail karger@karger.ch www.karger.com (c) 2009 S. Karger AG, Basel

0378-7346/09/0681-0019\$26.00/0

Accessible online at:

www.karger.com/goi
Prof. Ayman Al-Hendy, MD, PhD

1005 Dr. D.B. Todd Jr. Blvd., George Hubbard Hospital

5th Floor, Room 5131C

Nashville, TN 37208 (USA)

Tel. +1 615963 3148, Fax +1 615963 3125, E-Mail ahendy@MMC.edu 
have been reported to cause severe side effects such as an irreversible decrease in bone density and rapid regrowth of uterine tumors after treatment cessation [8]; therefore, use of this treatment has been restricted to a temporary (3-6 months) surgical adjuvant regimen [9].

Gene therapy implies delivery of genetic material to target cells to achieve therapeutic benefits such as interfering with a certain gene's function, restoring lost function, or initiating a new function [9]. Gene therapy utilizes the use of different strategies, the most frequent of which is suicide gene therapy [10]. Herpes simplex virus 1 thymidine kinase gene (HSV1TK) delivery followed by ganciclovir (GCV) administration (HSV1TK/GCV) is a common form of suicide gene therapy that has been applied to many tumors [11].

GCV, a nontoxic guanosine analog, is specifically phosphorylated by herpes simplex thymidine kinase into its monophosphorylate derivative (GCVMP), to which mammalian cellular kinases add additional phosphate groups, mediating its conversion to the toxic triphosphorylated form (GCVTP) [11]. Incorporation of this toxic metabolite into polymerizing DNA inhibits DNA synthesis and blocks the cell cycle, ultimately leading to cell death via apoptosis $[12,13]$. Intra-tumor delivery of the HSV1TK gene, followed by GCV administration, results in targeted killing of both HSV1TK-positive cells and neighboring negative cells via a phenomenon called the bystander effect [14-16]. This bystander phenomenon has been observed both in vitro [17] and in vivo [18].

The female Eker rat spontaneously develops uterine leiomyoma as a result of a germline mutation in the tuberous sclerosis 2 (Tsc-2) tumor-suppressor gene [19-21]. The similarity in pathogenesis of uterine leiomyoma in Eker rats and women has made these animals useful as a model system to experimentally address many issues related to this disease, including development of a new treatment modality [19].

Our previous in vitro studies demonstrated that adenoviral vectors were able to infect Eker rat uterine leiomyoma (ELT3) cells with optimal (100\%) transduction achieved at a multiplicity of infection (MOI) of 100 plaque-forming units (PFU)/cell [22]. We have also demonstrated that the adenovirus (Ad) efficiently transduced fresh uterine leiomyoma tissue disks $2-3 \mathrm{~mm}$ in diameter that were directly removed from hysterectomy specimens [9]. Furthermore, we have recently reported that the Ad vector expressing HSV1TK followed by GCV treatment severely inhibited cell proliferation and resulted in a marked increase in the number of apoptotic cells, as well as regression of ELT3 rat leiomyoma cell-based lesions implanted under nude mouse skin [16]. The current work is designed to assess the efficacy and safety of the in vivo Ad-HSV1TK/GCV suicide gene therapy approach of uterine leiomyomas in Eker rats, the only immune-competent animal model for uterine leiomyomas [19].

\section{Materials and Methods}

\section{Recombinant Adenovirus}

The Ad vector carrying the HSVITK gene under transcriptional control of the Rouse sarcoma virus (Ad-HSV1TK) used in this work has been described previously [23]. Ad-LacZ is a similar Ad expressing a marker gene coding for bacterial $\beta$-galactosidase; we used it as a negative control. Both viruses were kind gifts from Dr. Savio Woo (Mount Sinai School of Medicine, N.Y., USA). Large-scale production of Ad vectors was performed as described previously with a typical batch yield of $2 \times 10^{10} \mathrm{PFU} / \mathrm{ml}[24]$.

\section{Animals}

Female Eker rats, 11-14 months of age, were obtained from the closed colony at M.D. Anderson Cancer Center, Smithville, Tex., USA. The presence of uterine leiomyoma tumors was initially diagnosed with MRI scanning, as described previously [25, 26]. Rats harboring MRI-measurable tumors were randomized for either a single treatment with a direct intra-tumor injection of AdHSV1TK or with Ad-LacZ, which served as a negative control. All animals then received daily subcutaneous treatment with GCV $50 \mathrm{mg} / \mathrm{kg} /$ day for 10 days [27]. A 3rd group of animals receiving intra-tumoral injection of media alone (vehicle) was included as an additional negative control group. The tumor volume was determined by serial MRI scanning during the experiment course and confirmed with caliper measurement at times of injection and euthanasia. Sample rats (3/group) were selected randomly and euthanized at the following time points after treatment: 10, 20 , and 30 days (the end of the experiment). Blood and tissue samples were collected from tumors and several other organs. The rats were cared for and handled in accordance with the National Institutes of Health guidelines and they were housed in facilities accredited by the Association for the Accreditation of Laboratory Animal Care. All experiments were approved by the Institutional Animal Care and Use Committee (IACUC) of the University of Texas Medical Branch, Galveston, Tex., USA.

\section{Virus Dilution and Tumor Injection}

The final virus aliquot was diluted in serum-free medium and injected directly into the visible leiomyoma tumors after a minilaparotomy. We used the previously determined in vitro optimal MOI of 100 PFU/ELT3 cell [22]. The number of cells per tumor was determined using the general rule of $3 \times 10^{8} \mathrm{cell} / \mathrm{cm}^{3}$ of leiomyoma tumor [28]. The tumor volume was determined from the 3 diameters using the ellipsoid formula: volume $=\mathrm{R} 1 \times \mathrm{R} 2 \times$ $\mathrm{R} 3 \times 0.52$ [29]. The calculated virus volume was equally injected into the 4 tumor corners.

Tumor Tissue Evaluation

Tumor tissues collected from all groups were typically divided into 2 parts: one was immediately preserved in liquid nitrogen, 
and the other was formalin-fixed, paraffin-embedded, and subjected to hematoxylin and eosin (HE) histological analysis. The histological sections were graded semi-quantitatively for cell density (cellularity), the absence or presence of mitosis per 10 highpower fields, degree of variation in nuclear size, and hyaline changes as described previously [30].

Apoptosis was evaluated with the ApopTag kit (Intergen, Purchase, N.Y., USA) using the manufacturer's instructions. We evaluated Bax protein expression as representative for the apoptosis-related gene. We also evaluated immune cell infiltration by measuring the number of CD4+ and CD8+ cells using immunohistochemical analysis. The percentage of immunoreactive cells in all of these assays was calculated by counting both positively stained nuclei (brown color) against the total number of cells in 3 random high-power fields for each tissue section. Three tissue sections per animal were used and 3 animals were included from each group. Data are presented as mean \pm standard error (SE) of these 3 animals.

\section{Western Blot Analysis}

Small parts of liquid nitrogen-preserved tissues were washed twice with phosphate-buffered saline (PBS), and whole tissue lysates were prepared with RIPA lysis buffer. The following antibodies were purchased from Santa Cruz Biotechnology, Inc. (Santa Cruz, Calif., USA) and used at the following dilutions: $\mathrm{Bcl} 2$, 1:1,000; cyclin D1, 1:500; poly(ADP-ribose) polymerase (PARP), $1: 2,000$, and proliferating cell nuclear antigen (PCNA), 1:6,000, to detect their corresponding protein as described previously [31, 32].

\section{Caspase-3 Assay}

Caspase-3 enzyme activity was measured using the CaspACE Assay system (Promega Corp, Madison, Wisc., USA), in uterine leiomyoma tissues obtained from the Ad-HSV1TK/GCV-treated group and compared with control groups (Ad-LacZ/GCV group and medium-treated group). The assay was based on the ability of the caspase-3 enzyme to release the yellow chromophore P-nitroaniline (pNA) from the colorimetric substrate (Ac-DEVDpNA) provided in the CaspACE ${ }^{\mathrm{TM}}$ assay system [33]. Parts of liquid nitrogen-preserved tissues were washed twice with $1 \times$ PBS, suspended in $0.5 \mathrm{ml}$ ice-cold caspase lysis buffer, and then sonicated and left on dry ice for $20 \mathrm{~min}$. Lysates were centrifuged at $13,000 \mathrm{rpm}$ and $4^{\circ} \mathrm{C}$ for $5 \mathrm{~min}$ and supernatants were used for caspase- 3 assay. Fluorescence intensity was determined at 405(ex)/510(em) using the 96-plate Spectra max Gemini spectrofluorometer (Molecular Devices, Sunnyvale, Calif., USA). Relative caspase activities for each sample and sample plus inhibitor were calculated from the standard curve. Specific caspase-3 activity was calculated as the difference in cleavage activity between the absence and presence of the inhibitor. Caspase- 3 activity was normalized against the total protein content of each tissue measured by BCA kit and represented as percentage of control value.

\section{Safety and Toxicity Studies in Eker Rats}

All rats were examined daily for any unexpected complications or unexplained death. At the time of euthanasia, the ratio of uterine horn weight to total body weight was calculated, and samples from various organs including the uterus (myometrium and endometrium), ovary, cervix, vagina, liver, spleen, lung, kidney, and brain were collected and evaluated macroscopically and with HE staining by the same pathologist. Serum liver function tests (AST, ALT, and total bilirubin) were also evaluated using standard techniques [34].

To evaluate for possible dissemination of the Ad to distant rat organs after a single direct intra-fibroid injection, total DNA was isolated from various rat organs including the brain, lung, heart, liver, spleen, ovary, uterus, vagina, and cervix, as well as any uterine leiomyoma tumors, using the DNeasy Tissue kit (Qiagen Sciences, Germantown, Md., USA). The presence of Ad DNA was determined by sensitive polymerase chain reaction (PCR) amplification for the essential $\mathrm{E} 4$ region of the Ad genome as described previously $[16,35]$. The Ad genome was detected by the presence of an amplified 714-bp DNA fragment on 1\% agarose gel.

Evaluation of Anti-Ad5 Neutralization Antibody Titers

Anti-Ad5-neutralizing antibody titers were measured by the ability of serum to prevent Ad5 transfections of cultured cells as described previously [36-38].

\section{Statistical Analysis}

The data are presented as mean \pm SE. Group differences were analyzed using 1-way analysis of variance (ANOVA) followed by Tukey test as a post-ANOVA multiple comparison test. Caspase-3 assay results were analyzed using a 2-tailed unpaired t test. A p value of $<0.05$ was considered statistically significant.

\section{Results}

\section{Ad-HSV1TK/GCV Treatment Shrinks Uterine \\ Leiomyoma in the Eker Rat}

To evaluate the efficacy of the Ad-HSV1TK/GCV approach for the treatment of uterine leiomyoma, we used the Eker rat model. Initially, the presence of uterine fibroids was confirmed by both MRI and mini-laparotomy before the start of treatment. Animals treated with AdHSV1TK/GCV showed significant shrinkage in total tumor volume compared with the Ad-LacZ/GCV-treated group or the medium-treated group (fig. 1). Ad-HSV1TK/ GCV treatment produced marked shrinkage of the total uterine fibroid volume by $-75 \pm 16(\mathrm{p}<0.01),-58.7 \pm$ $6.3(\mathrm{p}<0.05)$, and $-67.5 \pm 27.5 \%(\mathrm{p}<0.01)$ of pretreatment volume at days 10, 20, and 30, respectively. The tumor size in control animals receiving Ad-LacZ/GCV continued to grow by $+26 \pm 10,+66 \pm 23$, and $+102 \pm$ $38 \%$ at the same time points when compared with pretreatment size. Similarly, the negative vehicle control group that received medium alone continued to grow by $+20 \pm 6,+70 \pm 8$, and $+110 \pm 15 \%$ at the same time points. There was no statistically significant difference between the 2 control groups (fig. 1). Additional statistical analysis for the tumor size changes within the AdHSV1TK/GCV treated group at days 10, 20 and 30, 
Fig. 1. Adenovirus-mediated delivery of the herpes simplex virus 1 thymidine kinase gene (Ad-HSV1TK; $3 \times 10^{10} \mathrm{PFU} / \mathrm{cm}^{3}$ of tumor) by a single direct injection into Eker rat uterine leiomyomata followed by subcutaneous injection of ganciclovir (GCV; 50 $\mathrm{mg} / \mathrm{kg} /$ day) for 10 days significantly shrinks Eker rat uterine leiomyoma volume when compared with both Ad-LacZ/GCV and vehicle-treated animal groups. Uterine leiomyoma tumor volume was measured by both MRI scanning and caliper measurement. Tumor volume was calculated as a percentage from day 0. Each time point represents the mean \pm SE of 3 animals. ${ }^{\text {a, b }}$ Significant difference from control and Ad-LacZ/GCV-treated groups, respectively, at $\mathrm{p}<0.05$ using the Tukey test as a post-ANOVA test.
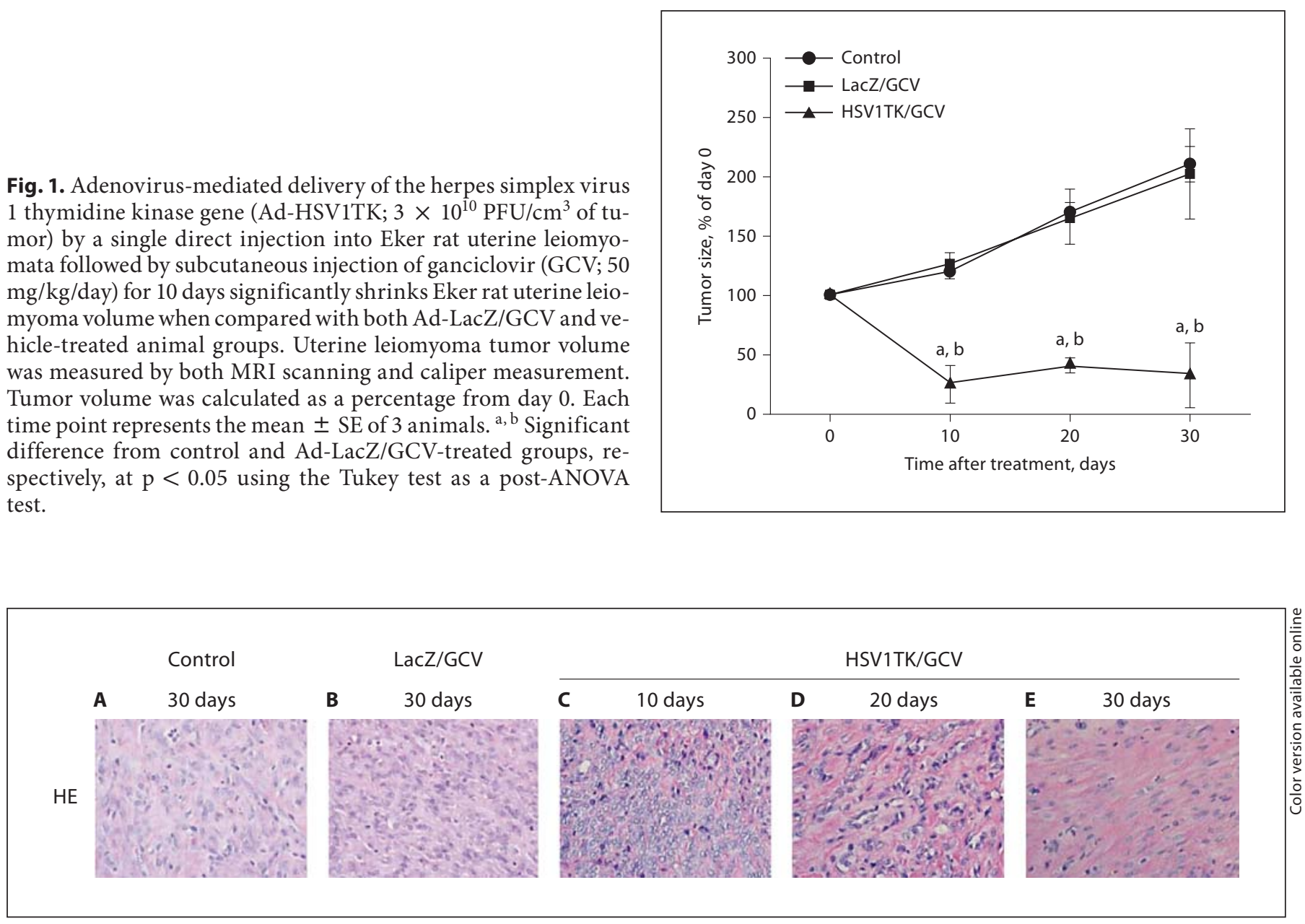

Fig. 2. Representative micrographs for HE-stained sections from Eker rat uterine leiomyomata treated with Ad-HSV1TK/GCV collected 10 (C), 20 (D), and 30 days (E) after treatment versus Ad-LacZ/GCV (B) and vehicle (control)-treated (A) sections. HE sections of the Ad-LacZ/GCV or control-treated leiomyomata showed bundles of smooth muscle cells of various sizes running in different directions. Those cut longitudinally showed cylindrical nuclei, eosinophilic cytoplasm, and ill-defined cell outlines.
The nuclei were uniform, and the mitotic figures were absent or sparse. When the cells were transversely cut, their nuclei appeared circular with clear cytoplasm surrounding them. The muscle fibers were intermixed with fibrous connective tissue. HE sections of Ad-HSV1TK/GCV-treated leiomyomata showed bundles of edematous smooth muscle cells; the nuclei were smaller in size and had a rounded oval shape. No mitotic activity was seen, and the cellularity was decreased. showed that there was no significant difference in tumor size among these time points indicating that the treatment-induced tumor shrinkage was persistent for the full duration of the treatment (30 days).

\section{Histological Changes in Ad-HSV1TK/GCV-Treated Rat Fibroid Lesions}

HE-stained sections prepared from both control and Ad-LacZ/GCV-treated rats (fig. 2A, B) showed typical fibroid histology consisting of bundles of smooth muscle cells of various sizes running in different directions.
Longitudinally cut sections showed cylindrical nuclei, eosinophilic cytoplasm, and ill-defined cell outlines. The nuclei were uniform, crowded, and tightly packed, and the mitotic figures were sparse. The muscle fibers were intermixed with fibrous connective tissue. Occasional hyaline changes were visible (fig. $2 \mathrm{~A}, \mathrm{~B}$ ). Conversely, HE-stained sections of Ad-HSV1TK/GCV-treated rat leiomyoma (fig. 2C-E) showed bundles of edematous smooth muscle cells, and the nuclei were smaller in size and oval-shaped with marked nuclear vacuolization and degeneration. No mitotic activity was seen; the cel- 


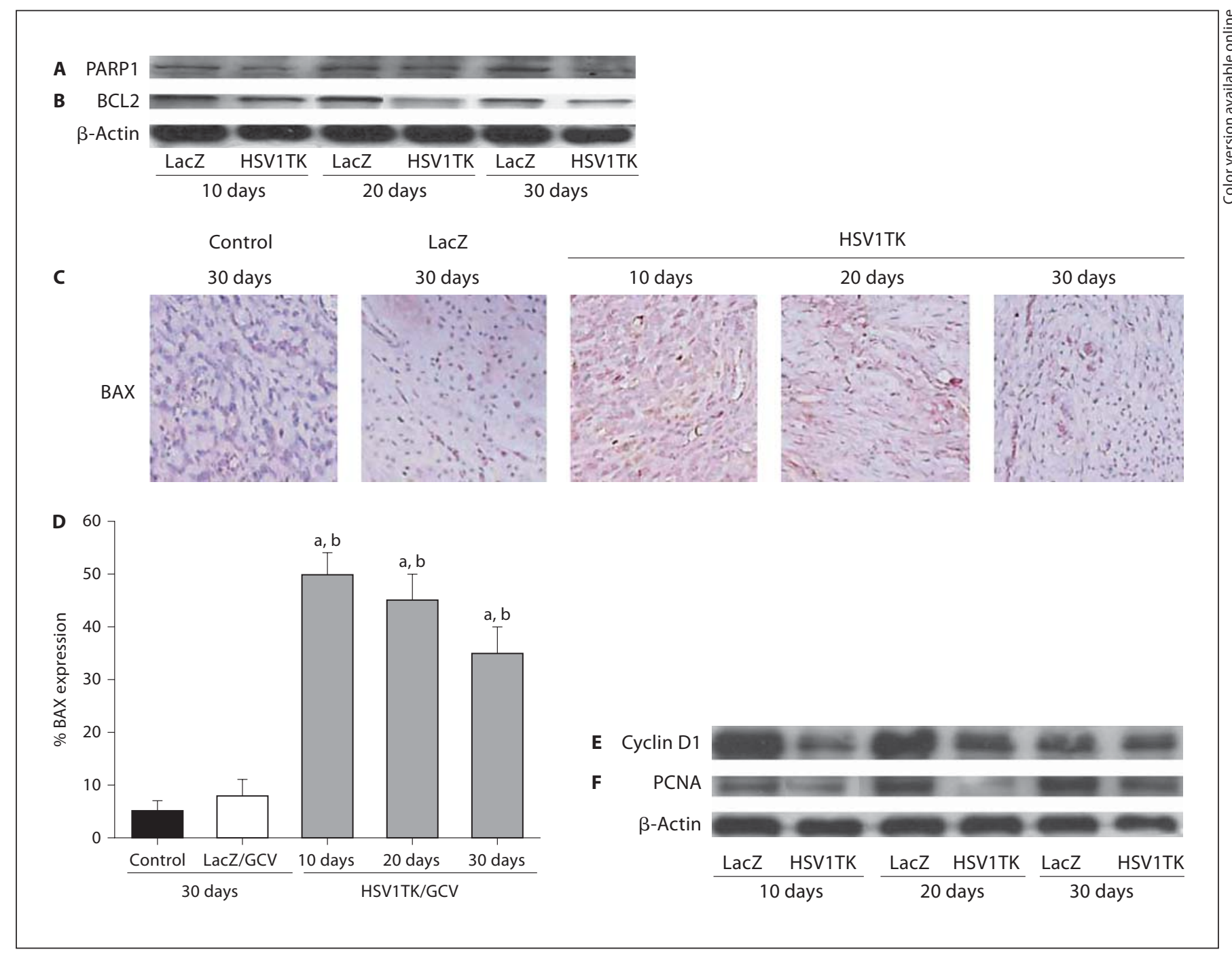

Fig. 3. Ad-HSV1TK/GCV treatment modulates both apoptosisand proliferation-related gene expression in Eker rat uterine leiomyomata. Western blot analysis of protein extracted from Eker rat uterine leiomyoma tissue treated with Ad-HSV1TK/GCV exhibited a remarkable decrease in the expressions of both the antiapoptotic protein $\mathrm{Bcl} 2$ (B) and the death substrate PARP (A). Immunohistochemical analysis of Eker rat uterine leiomyoma sections treated with Ad-HSV1TK/GCV revealed a significant in- crease in the pro-apoptotic Bax protein at all time points (C, D). Western blot analysis of the same tissue samples revealed that the Ad-HSV1TK/GCV treatment resulted in a decrease in proliferation-regulating gene expression, cyclin D1 (E) and proliferating nuclear antigen (PCNA; F). ${ }^{\text {a b }}$ Significant difference from control and Ad-LacZ/GCV-treated animals, respectively, at $\mathrm{p}<0.05$ using the Tukey test as a post-ANOVA test. lularity was remarkably decreased, and hyalinization was a widespread, prominent feature, especially at day 30 (fig. 2E).

\section{Ad-HSV1TK/GCV Treatment Induces Apoptosis and} Inhibits Proliferation in Eker Rat Uterine Leiomyoma Ad-HSV1TK/GCV treatment induced a clear decrease in both anti-apoptotic $\mathrm{Bcl} 2$ (fig. $3 \mathrm{~B}$ ) and the death substrate, PARP1 protein expressions, as assessed by Western blot (fig. 3A). As detected by immunohistochemistry, Ad-HSV1TK/GCV treatment significantly $(p<0.05)$ increased the expression of the pro-apoptotic Bax protein at all selected time points $(10,20$, and 30 days) when compared with medium control or Ad-LacZ/ GCV-treated groups (fig. 3C, D). Additionally, Ad-HSV1TK/GCV led to a clear reduction in the expression of 

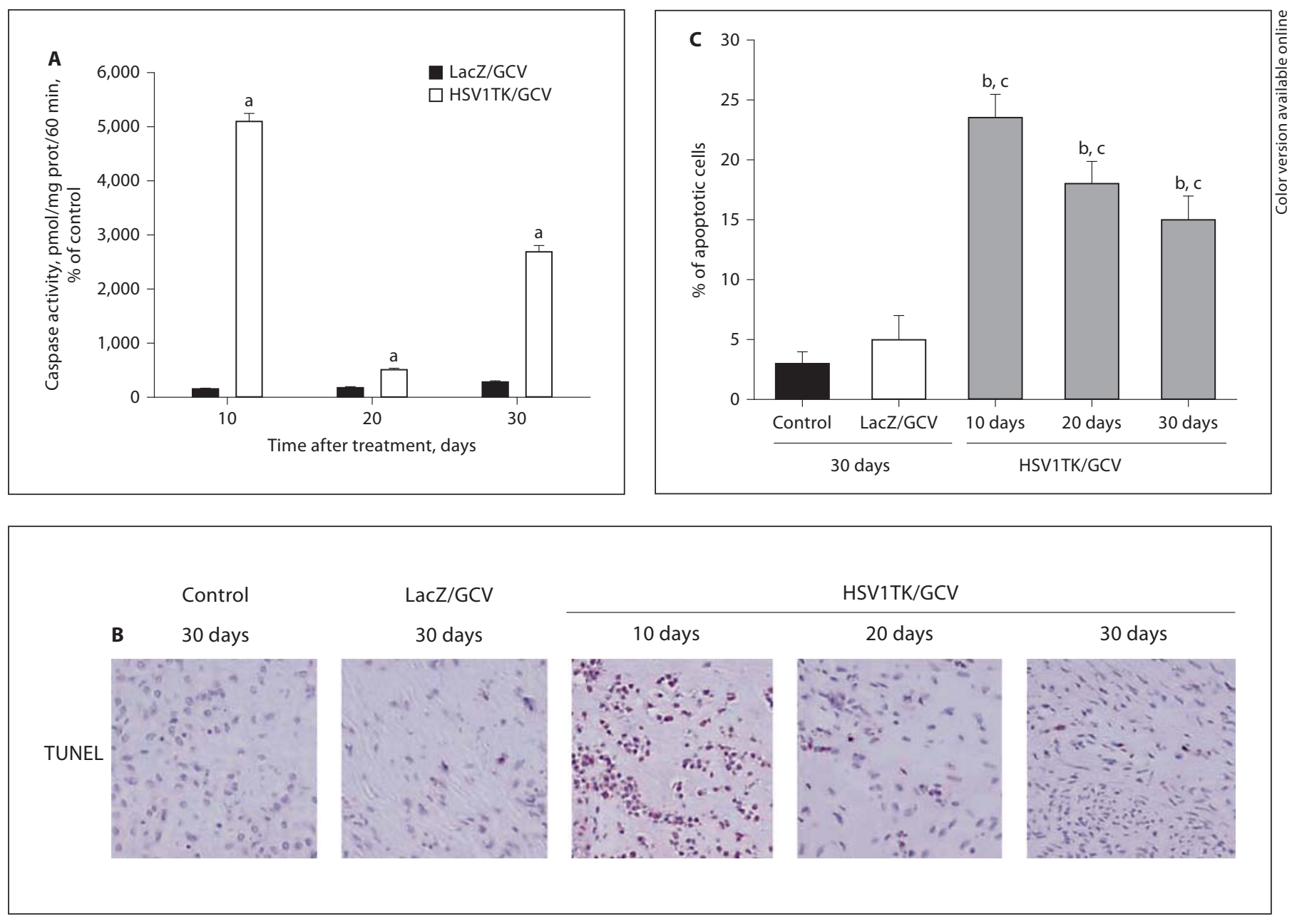

Fig. 4. Ad-HSV1TK/GCV treatment significantly increased caspase-3 activity in Eker rat uterine leiomyomata at all selected time points when compared with the Ad-LacZ-treated group (A). The number of apoptotic cells were significantly increased, which is indicated by an increase in positive TUNEL reactions in tissue sections prepared from Ad-HSV1TK/GCV-treated animals when compared with either control or Ad-LacZ/GCV-treated tumor sections (B). Caspase-3 activity was normalized against the total

both PCNA, an endogenous marker for proliferation [39], and cyclin D1, a cell cycle-regulating gene (fig. 3E, F) [40].

Further confirming the induction of apoptosis in Ad-HSV1TK-treated Eker rat fibroid lesions, the AdHSV1TK/GCV-treated group exhibited a significant increase in caspase- 3 activity, 5,103, 500, and $2,686 \%$ of the corresponding caspase- 3 values in media-treated animals at 10,20, and 30 days, respectively, when compared with Ad-LacZ/GCV-induced caspase-3 activity of 144, 171 , and $277 \%$ of the corresponding control group at the protein content of each tissue measured by BCA kit. Caspase- 3 activity was represented as percentage of control. Apoptotic cells are represented as a percentage of total cells in the field (C). ${ }^{\text {a }}$ Significant difference from Ad-LacZ/GCV at $\mathrm{p}<0.001$ using a 2tailed unpaired $t$ test in the caspase- 3 activity experiment. ${ }^{b, c}$ Significant difference from sections treated with either control or Ad-LacZ/GCV at $\mathrm{p}<0.05$ using the Tukey test as a post-ANOVA test.

same time points ( $\mathrm{p}<0.01$; fig. $4 \mathrm{~A})$. Similar findings were observed in the TUNEL reaction. The percentages of apoptotic TUNEL-positive cells were $23 \pm 2,18 \pm 2$, and $15 \pm 2 \%$ in fibroid tissues collected from Ad-HSV1TK/ GCV-treated rats at 10,20 , and 30 days after treatment compared with $2.8 \pm 0.7,2.5 \pm 1.5$, and $3 \pm 1 \%$ in the media-treated group, and $4.7 \pm 2.8,3.8 \pm 1.5$, and $5 \pm$ $2 \%$ in Ad-LacZ/GCV-treated rats at the same time points ( $p<0.05$; fig. 4B; day 30 results representative for both control and Ad-LacZ groups). 


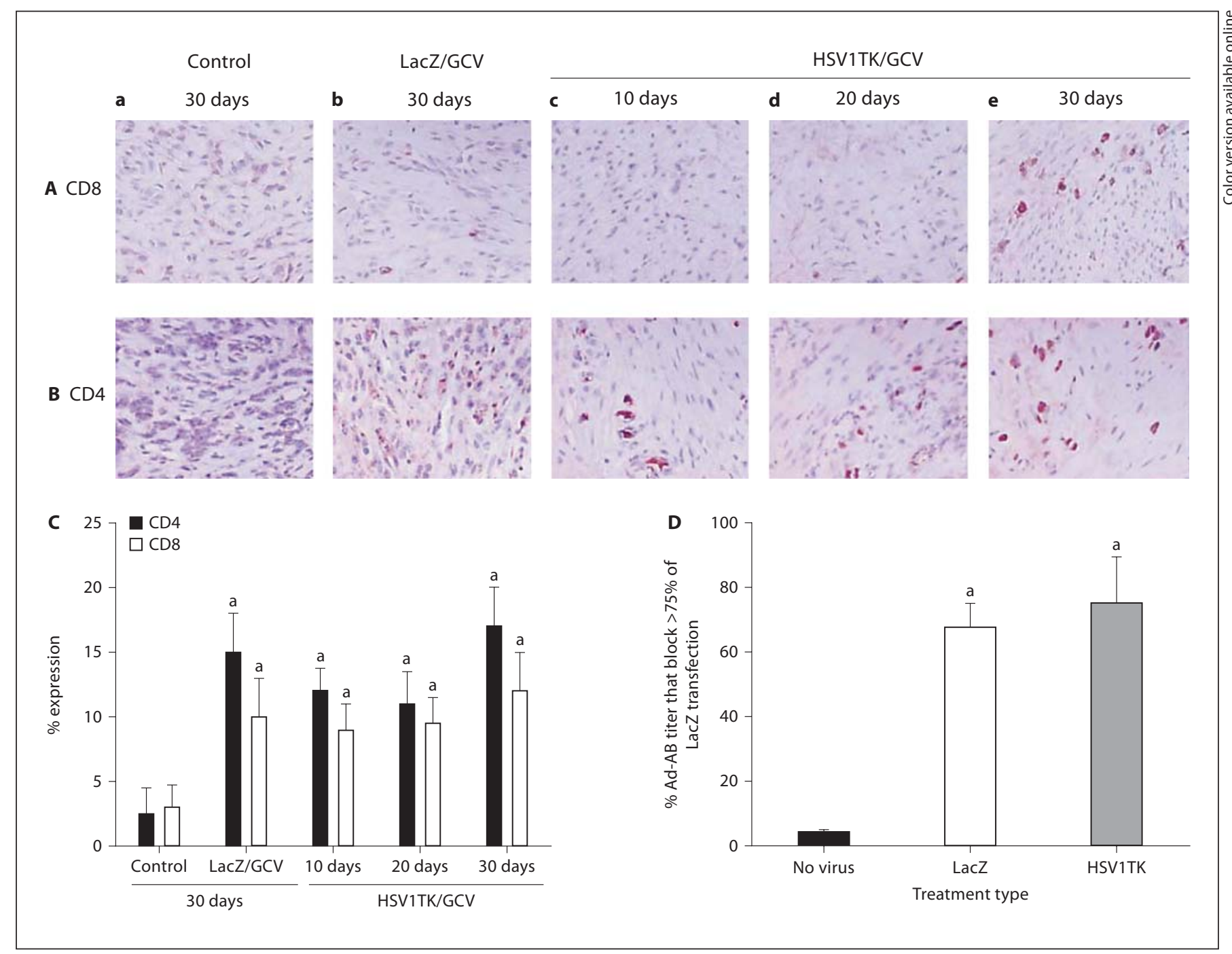

Fig. 5. Evaluation of the immunoresponse after a single direct adenovirus (Ad) injection into Eker rat uterine leiomyoma. Representative tumor sections from control (a), Ad-LacZ (b), AdHSV1TK collected after 10 (c), 20 (d), and 30 (e) days stained with antibodies against CD8 (A) or CD4 (B) as indicators for local immune response activation. The amount of both CD4+ and CD8+ cells was significantly higher in Ad-treated tissue sections compared with control. The number of $\mathrm{CD} 4+$ or CD8+ cells was counted in 4 random fields of each section representing 1 animal, calculated as a percentage of total cells, and plotted as mean \pm SE of 2 animals for each point (C). Intrauterine leiomyoma injection of Ad-induced anti-Ad antibodies in Eker rat serum 30 days after injection as ultimate for humoral immune response (D). The sera were serially diluted using OPTI medium, heat inactivated, incubated with Ad-LacZ for $1 \mathrm{~h}$ at $37^{\circ} \mathrm{C}$, and then used for transfection of human leiomyoma cells. After $24 \mathrm{~h}$, the cell cultures were fixed and stained with X-gal stain. The number of blue-stained nuclei were calculated as a percentage of total cells in the field. Antibody titer was calculated as the highest serum dilution that blocks $>75 \%$ of Ad-LacZ transfection. Ad-LacZ without Eker rat serum was used as a positive control. Eker rat serum known to be negative for Ad-antibodies was used as negative control. ${ }^{\text {a Significant }}$ difference from negative control (no virus-treated group) at $\mathrm{p}<$ 0.05 using the Tukey test as a post-ANOVA test.

\section{Local Immune Cell Infiltration after a Single}

Intra-Fibroid Injection of Ad-HSV1TK

Ad injections significantly $(\mathrm{p}<0.05)$ increased the number of CD4+ and CD8+ cells compared with medium-treated control (fig. 5A-C). Leiomyoma sections pre- pared from Ad-LacZ-treated animals 10, 20, and 30 days after treatment exhibited $10 \pm 4,11 \pm 4$, and $15 \pm 3 \%$ CD4+ expressions while Ad-HSV1TK-treated sections exhibited $12 \pm 1.7,11 \pm 2.5$, and $17 \pm 3 \%$, respectively, compared with $1.5 \pm 2,3 \pm 4$, and $2.5 \pm 2 \%$ in control 


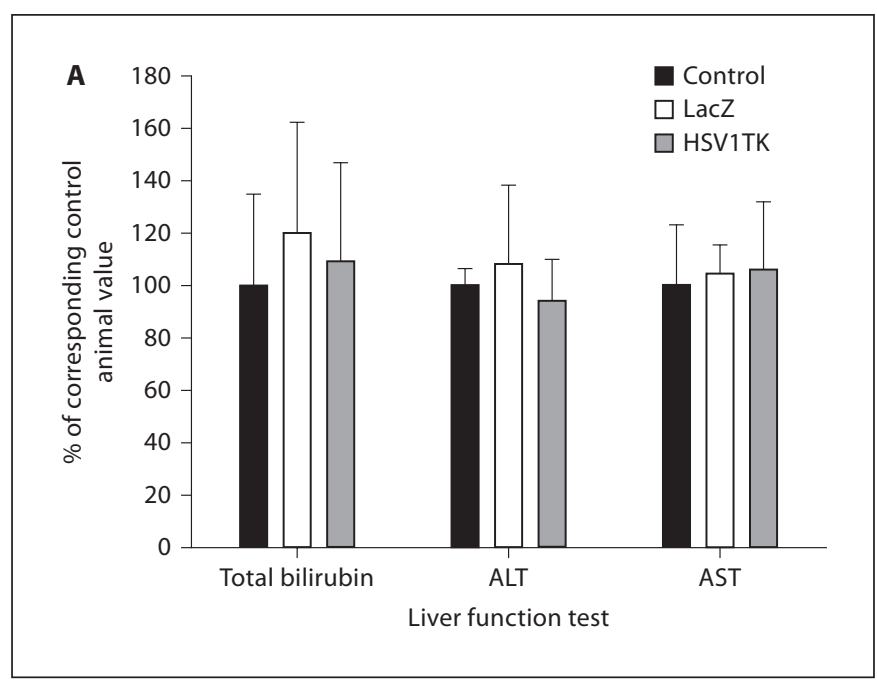

Fig. 6. Evaluation of Ad-HSV1TK/GCV safety in the Eker rat after a single intrauterine Ad-HSV1TK injection followed by 10 daily doses of GCV. There were no significant changes in either liver

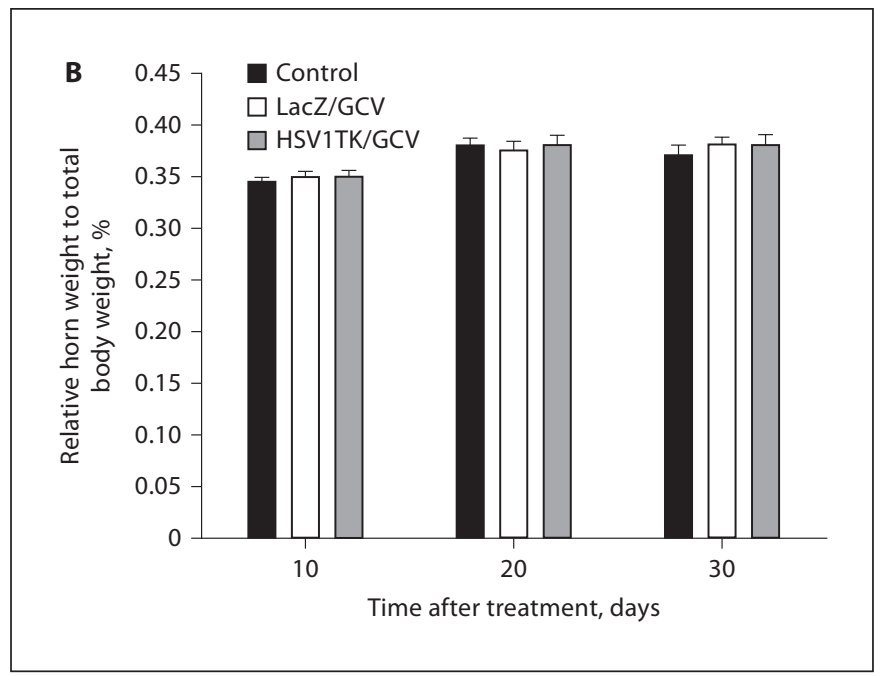

function test evaluated 30 days after adenovirus treatment $(\mathbf{A})$ or relative horn weight to total body weight during the treatment course (B).

Table 1. Evaluation of adenovirus dissemination in Eker rat organs after a single intrauterine leiomyoma injection of $3 \times 10^{10} \mathrm{PFU} / \mathrm{cm}^{3}$ tumor

\begin{tabular}{lllllllllll}
\hline & \multicolumn{2}{l}{ Animal organ } & & & & \\
& brain & heart & lung & liver & spleen & kidney & ovary & uterus & vagina cervix \\
\hline $\begin{array}{c}\text { Percentage of E4-positive organ } \\
\text { to total number of animals }\end{array}$ & 0 & 0 & 0 & 30 & 0 & 0 & 0 & 20 & 0 & 0 \\
\hline
\end{tabular}

The results are the sum from both Ad-LacZ and Ad-HSV1TK groups 10 days after Ad injection.

tissue at the same time points mentioned previously. The percentage expression of CD8+ cells in Ad-HSV1TKtreated leiomyoma was $9 \pm 2,9.5 \pm 2$, and $12 \pm 2 \%$, respectively, in the same treatment order mentioned previously. In Ad-LacZ, the expression was $8 \pm 4,10 \pm 2$, and $10 \pm 3 \%$, compared with $3 \pm 2,2.5 \pm 3$, and $3 \pm$ $1.75 \%$ expressed in sections prepared from control animals (fig. 5A-C; day 30 results were representative for control and Ad-LacZ groups).

\section{Humoral Immune Response to Adenovirus Treatment} in Eker Rats

Contrary to our predictions, direct injection of AdLacZ or Ad-HSV1TK into uterine fibroid lesions in the Eker rat elicited a systemic anti-Ad antibody humoral response. Undiluted sera from non-virus medium-only treated control group animals did not block the Ad transfection and exhibited optimal Ad transfection after a 1:4 dilution. Conversely, higher antibody titers of $67.5 \pm 7.5$ $(\mathrm{p}=0.01)$ and $75 \pm 14.4(\mathrm{p}=0.01)$ were detected for AdLacZ and Ad-HSV1TK-treated Eker rats 30 days after treatment, respectively (fig. 5D).

\section{Safety and Toxicity Studies}

The effectiveness of any tumor therapy must be weighed carefully against its risks or side effects. In this study, all treated rats tolerated the virus inoculation well and survived the experiment without any apparent sign of toxicity. The Ad-HSV1TK/GCV treatment strategy did not produce any significant effect on Eker rat liver function tests (AST, ALT, and total bilirubin) after 30 days of Ad injections (fig. 6A). These values were comparable 

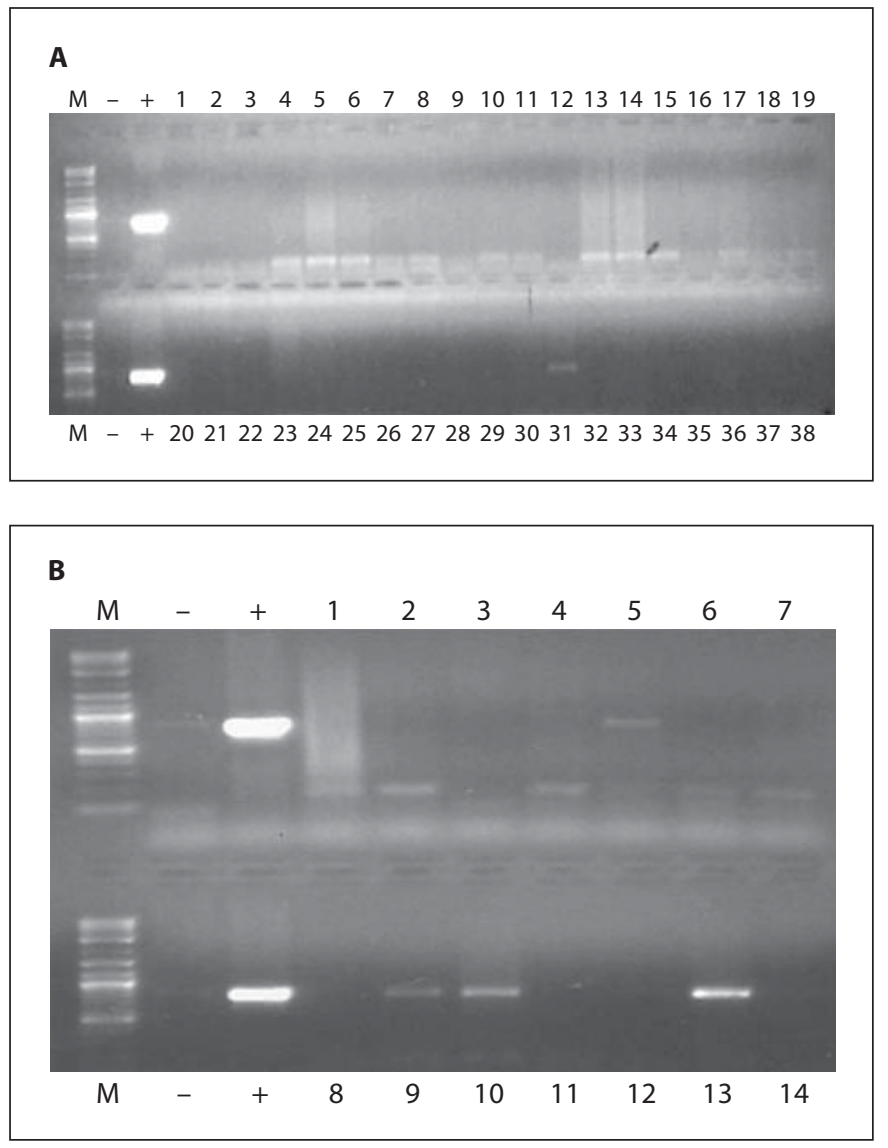

Fig. 7. Evaluation of Ad-HSV1TK dissemination in Eker rat organs after a single intrauterine leiomyoma injection of $3 \times 10^{10}$ $\mathrm{PFU} / \mathrm{cm}^{3}$ tumor. Total DNA was isolated from tumor tissue and most animal organs as described in the Materials and Methods section. We then performed PCR amplification of the Ad E4 region, and the presence of the $\mathrm{E} 4$ region was documented on $1 \%$ agarose gel. The 714-bp DNA fragment corresponding to the Ad $\mathrm{E} 4$ region was clearly detected in tumor tissues (B10 and B13), while faint bands were detected in 30\% of liver (A31 and B5) and $20 \%$ of myometrium tissues (B9). The other organs showed negative results. These results are the sum of both Ad-LacZ and Ad-TK groups at 10 days after Ad injection.

with values obtained from medium-treated controls and the Ad-LacZ/GCV-treated group. There was no significant change in relative uterine horn weight to total body weight among various treatment groups at 10,20 , and 30 days (fig. 6B)

Histological evaluation of tissue sections obtained from different Eker rat organs at all of the tested time points using HE staining revealed no sign of tissue damage or necrosis. PCR amplification of the Ad-E4 region indicated that the Ad was localized in the injected tumor tissues and, to a much lesser degree, in the liver and uterine tissues (fig. 7; table 1). None of the other tested organs demonstrated the presence of any amplifiable Ad DNA.

\section{Discussion}

Suicide gene therapy represents an appealing option for the treatment of many pathologic conditions of cellular hyperproliferation, including tumors [41-43]. The HSV1TK/GCV approach, a popular form of suicidal gene therapy, has been reported as an effective strategy for the treatment of several human tumors [14, 18, 24, 42, 44, 45]. We have recently demonstrated that Ad-mediated delivery of HSV1TK, followed by GCV treatment, was toxic to human and rat leiomyoma cells in vitro and induced a remarkable regression of ELT3 cell-based lesions in nude mice [16]. In a continuation of our efforts to develop an alternative localized nonsurgical treatment approach for uterine leiomyoma, it was important to test this therapeutic modality in an immunocompetent animal model of uterine leiomyoma to assess both treatment safety and efficiency in preparation for a possible future clinical trial.

In this study, we investigated whether gene transfer using an Ad vector expressing HSV1TK followed by GCV treatment would be useful in reducing uterine leiomyoma size in the Eker rat model. Our data clearly demonstrate that the Ad-HSV1TK/GCV approach is very efficient in decreasing Eker rat uterine leiomyoma volume. Moreover, statistical analysis for the tumor size changes within the Ad-TK treated group at days 10, 20 and 30 using Tukey test as a post-ANOVA test demonstrated no significant difference in tumor size among these time points, indicating that the treatment-induced tumor shrinkage was persistent for the full duration of the treatment (30 days; fig. 1), which may reflect the bystander phenomenon of the HSV1TK/GCV approach [14-16]. It is expected that adenovirus vectors would be cleared from the transfected tissues within 6-8 weeks depending upon the severity of local immune response [46-49]. Thus the biological response would be optimal within the first few weeks and start to decrease gradually. Currently, we do not have long-term ( $>30$ days) data with this approach in the Eker rat model. However, we have shown earlier that repeated adenovirus injection could be effective [24]. Additionally, we are evaluating the utility of modified adenoviral vectors that might support enhanced and prolonged gene expression [50].

In order to elucidate the potential mechanisms by which Ad-HSV1TK/GCV could mediate the Eker rat tu- 
mor size shrinkage, we evaluated various genes implicated in cellular pathways that have been reported to be altered in leiomyomas, such as proliferation (PCNA and cyclin D1) and apoptosis (Bax, Bcl2, PARP), as well as caspase- 3 activity. Finally, we confirmed the apoptosis by TUNEL assay.

It is well known that the basic machinery for apoptosis constitutes a complex interaction between distinct proand anti-apoptotic molecules such as Bcl2 family members [51]. Bcl2, a major anti-apoptotic protein, has been shown to block apoptosis by preventing loss of mitochondrial membrane potential, which blocks cytochrome c release [52] and prevents the activation of the caspase cascade [53]. On the other hand, Bax (a pro-apoptotic protein) has been reported to mediate the opposite effect of the $\mathrm{Bcl} 2$ protein $[51,54]$. Leiomyoma cells have been reported to express higher amounts of $\mathrm{Bcl} 2$ protein and lower amounts of Bax proteins compared with normal myometrial cells $[55,56]$. In this study, Ad-HSV1TK/ GCV treatment significantly reduced the expression of $\mathrm{Bcl} 2$ protein and increased Bax protein expression at all time points, which conceivably would lead to activation of a caspase cascade [53].

PARP, a nuclear enzyme, plays a crucial role in DNA replication, transcription, repair, and genome stability $[57,58]$. PARP cleavage has been used as a prominent biochemical hallmark of apoptosis $[58,59]$. The activation or upregulation of the PARP protein was more frequently detected in leiomyomas as compared with myometria [60]. In this study, of particular importance was the decrease in the expression of PARP in Eker rat uterine leiomyoma treated with Ad-HSV1TK/GCV compared with control. This finding strongly implicates caspase cascade activation.

It is well documented that caspase-3, the effector executioner of apoptosis, is working in part through cleavage of the parent PARP compound into its inactive fragment, leading to inhibition of DNA repair and resulting in apoptosis [52, 59, 61]. Our data clearly demonstrated significant induction of caspase-3 activity at all selected time points compared with control animals. As expected, these effects resulted in the overall increase in the percentage of TUNEL-positive apoptotic cells in AdHSV1TK/GCV-treated groups compared with control groups.

Accumulating evidence indicated that uterine leiomyoma growth is, in part, regulated by the balance between genes regulating proliferation and apoptosis [62, 63]. PCNA and cyclin D1 have been demonstrated as markers of proliferation $[40,62,64]$ and have been reported to be higher in leiomyoma than in a normal myometrium compartment [62]. Ad-HSV1TK/GCV exhibited a dramatic decrease in PCNA and cyclin D1 expression (fig. 3E, F), which might reflect a cell cycle arrest $[40,62,64]$. Taking these results together, we can conclude that Ad-HSV1TK/ GCV treatment shrinks Eker rat leiomyomas, in part, through induction of apoptosis and inhibition of proliferation.

There is ample evidence indicating the effect of the immunoresponse on the usefulness of Ad-mediated gene therapy in vivo $[65,66]$. In the context of tumors, the immune system would have controversial effects: it would augment the cytotoxic effect on tumor cells through the innate destructive cellular immune responses against the virus-transuded cells [65], and it could neutralize the Ad that carries the gene of interest, which would eliminate transgene expression and reduce gene transfer efficiency [66].

In this study, the interplay between the Ad and the immune system has been assessed by evaluating the cluster of differentiation 4 and 8 (CD4+ and CD8+) cells. These cells are representative of the local immune response, as well as the Ad antibodies serum titer, as the ultimate for humoral immune response, exploiting the immunocompetent nature of Eker rat (fig. 5). CD4+ cells amplify the signal generated by the T-cell receptor in response to infection, regulating both the innate and adaptive immune responses [67], while CD8+ T cells release cytotoxins that form pores in the plasma membrane of cells infected with viruses, which eventually leads to target cell apoptosis $[68,69]$.

Our studies have demonstrated that the percentage of both CD4+ and CD8+ cells was significantly increased in all Ad-treated uterine leiomyoma tissue compared with the vehicle-treated group (fig. 5A-C). Interestingly, the results are comparable between Ad-LacZ and AdHSVT1K animals indicating that the local immune response represented by CD4+ and CD8+ cells is directed towards the adenovirus back bone and not the transgene. On the other hand, the tumor shrinkage and other biological effects like apoptosis are due to the therapeutic HSV1TK transgene. This finding is consistent with earlier reports by us and others $[24,49,70]$.

Our results also reported a moderate induction in the level of Ad antibodies in the Eker rat sera after a direct single intrauterine injection of Ad-HSV1TK or Ad-LacZ (fig. 5D). However, we do not expect a significant effect on gene transfer using repeated Ad injections (if required to achieve higher tumor cell eradication), since uterine leiomyoma are developed as discreet and circumscribed 
within a fibrous capsule [9]; this facilitates direct Ad targeting inside the tumor avoiding serum antibody neutralization in the future. We and others have demonstrated that repeated adenovirus injection directly into tumors is efficacious even in the presence of anti-adenovirus antibodies [16, 24, 70, 71, 72].

From a clinical point of view, Ad-mediated gene therapy for uterine leiomyomas has to avoid toxic side effects to other cell populations within the uterus as well as body organs, specifically, the liver - a target for systemically injected Ad toxicity [73, 74]. Careful review of different body organ histology, especially the hepatic and uterine tissues in Ad-HSV1TK/GCV animals at all scheduled experiment time points $(10,20$, and 30 days) did not reveal any evidence of organ damage. The liver function test and the percentage of horn weight to total body weight did not reveal any significant changes compared with either control or Ad-LacZ/GCV-treated animals, which solidifies the safety profile of this treatment regimen (fig. 6). Similar dose regimens up to 30 days have been applied in various clinical trials against different disease models with excellent safety profile [75-77].

Moreover, we did not find evidence of significant dissemination of our target gene to distal body organs; this was probably due to the capsulated nature of leiomyoma tissue and the localized method of virus delivery. The only exception was the liver and the uterus, which showed infrequent dissemination in $30 \%$ of the Ad-injected animals (fig. 7; table 1). The level of leakage/rat seems to be minimal since the PCR amplicon was very faint (fig. 7). Similar findings have been reported before by our group and others $[16,18,78]$. We and others have also utilized similar methods for Ad detection in both preclinical and clinical trials $[16,35]$. Our attempts to modify the liver tropism of wild-type adenovirus and divert it to the target organ of choice are yielding encouraging results [50,79].

Applying this treatment modality for human uterine leiomyoma could be a successful option due to the inherent features of leiomyomas: fibrous capsulated nature, slow-growing tumor rate, and the fact that marked clinical improvement of fibroid-related symptoms does not necessitate complete resolution of the fibroid but rather a modest decrease in size $[5,9,80,81]$. Minimally invasive ultrasound-guided transcutaneous injection of the virus directly into the uterine fibroid lesion would be a feasible option. A delivery system, such as VacLok with pressure sensing (http://www.medicaldesignonline.com), could avoid injection site transfection, or using a modified targeted (enhanced) Ad vector transvaginally could avoid dissemination $[50,80]$.

Ad-HSV1TK/GCV Therapeutic Approach and Eker Rat Fibroids
Worldwide, over 1,300 clinical trials were done by the end of July 2007, and still Ad vectors are the most commonly used vector $[82,83]$. Most of these clinical trials were determining the safety of the agents (phase I) or their potential efficacy (phase II) [75, 77, 84, 85].

Gynecology and gynecologic oncology are at the forefront of evolving gene therapy towards both benign and malignant disease [86, 87]. Gynecologic gene therapy has advanced to human clinical trials for ovarian carcinoma $[86,87]$; a phase III human clinical trial has begun in patients with stage III epithelial ovarian cancer [88]. Similar strategies are at early stages, for endometrial carcinoma [89-90], breast cancer [91], cervical cancer [92], and other benign gynecological disorders such as endometriosis [93], ovarian failure [94] and adhesion [95].

Gene therapy success for a genetic disease - severe combined immunodeficiency disease - has been achieved $[86,96]$, and ongoing gene therapy development includes choosing the appropriate gene, method of gene delivery, achieving temporary or stable transfection, regulating gene expression, avoiding side effects and achieving better results than conventional therapy $[47,50,71,78,79,86]$.

In conclusion, our work clearly demonstrates a marked efficiency and high safety margin for the Ad-HSV1TK/ GCV therapeutic approach in the context of Eker rat uterine leiomyoma. The tumor shrinkage is mediated via induction of apoptosis and decreasing the proliferation. This study may lead to a clinical trial as the next step in developing an effective, targeted, nonsurgical treatment option, especially for patients who want to maintain their fertility.

\section{Acknowledgments}

Sources of Financial Support: NIH/NICHD 1 R01 HD04622801 to AA. This publication was also made possible by grant number G12 RR03032 from the National Center for Research Resources (NCRR), a component of the National Institutes of Health (NIH), and 'its contents are solely the responsibility of the authors and do not necessarily represent the official views of NCRR or NIH'. 


\section{References}

1 Stewart EA: Uterine fibroids. Lancet 2001; 357:293-298.

-2 Farhi J, Ashkenazi J, Feldberg D, Dicker D, Orvieto R, Ben Rafael Z: Effect of uterine leiomyomata on the results of in-vitro fertilization treatment. Hum Reprod 1995; 10 : 2576-2578.

-3 Hart R, Khalaf Y, Yeong CT, Seed P, Taylor A, Braude P: A prospective controlled study of the effect of intramural uterine fibroids on the outcome of assisted conception. Hum Reprod 2001;16:2411-2417.

-4 Surrey ES, Lietz AK, Schoolcraft WB: Impact of intramural leiomyomata in patients with a normal endometrial cavity on in vitro fertilization-embryo transfer cycle outcome. Fertil Steril 2001;75:405-410.

5 Vilos GA: Uterine fibroids: relationships to reproduction. Minerva Ginecol 2003;55: 417-423.

6 Walker CL, Stewart EA: Uterine fibroids: the elephant in the room. Science 2005;308: 1589-1592.

-7 Lefebvre G, Allaire C, Jeffrey J, Vilos GA, Arneja J, Birch C, Fortier M; Clinical Practice Gynaecology Committee and Executive Committee and Council, Society of Obstetricians and Gynaecologists of Canada: SOGC clinical guidelines. Hysterectomy. J Obstet Gynaecol Can 2002;24:37-76.

\$ Andreyko JL, Marshall LA, Dumesic DA, Jaffe RB: Therapeutic uses of gonadotropinreleasing hormone analogs. Obstet Gynecol Surv 1987;42:1-21.

$\checkmark$ Al Hendy A, Salama S: Gene therapy and uterine leiomyoma: a review. Hum Reprod Update 2006;16:385-400.

10 Vassaux G, Martin-Duque P: Use of suicide genes for cancer gene therapy: study of the different approaches. Expert Opin Biol Ther 2004;4:519-530.

-11 Tasciotti E, Zoppe M, Giacca M: Transcellular transfer of active HSV-1 thymidine kinase mediated by an 11-amino-acid peptide from HIV-1 Tat. Cancer Gene Ther 2003;10: 64-74.

12 Reid R, Mar EC, Huang ES, Topal MD: Insertion and extension of acyclic, dideoxy, and ara nucleotides by herpesviridae, human-alpha and human-beta polymerases: a unique inhibition mechanism for 9-(1,3-dihydroxy2-propoxymethyl)guanine triphosphate. J Biol Chem 1988;263:3898-3904.

13 Robe PA, Princen F, Martin D, Malgrange B, Stevenaert A, Moonen G, Gielen J, Merville MP, Bours V: Pharmacological modulation of the bystander effect in the herpes simplex virus thymidine kinase/ganciclovir gene therapy system: effects of dibutyryl adenosine 3', 5'-cyclic monophosphate, alpha-glycyrrhetinic acid, and cytosine arabinoside. Biochem Pharmacol 2000;60:241-249.
14 Palu G, Cavaggioni A, Calvi P, Franchin E, Pizzato M, Boschetto R, Parolin C, Chilosi M, Ferrini S, Zanusso A, Colombo F: Gene therapy of glioblastoma multiforme via combined expression of suicide and cytokine genes: a pilot study in humans. Gene Ther 1999;6:330-337.

15 Rubsam LZ, Boucher PD, Murphy PJ, KuKuruga $M$, Shewach DS: Cytotoxicity and accumulation of ganciclovir triphosphate in bystander cells cocultured with herpes simplex virus type 1 thymidine kinase-expressing human glioblastoma cells. Cancer Res 1999;59:669-675.

16 Salama S, Kamel M, Christman G, Wang H, Al-Hendy A: Gene therapy of uterine fibroids: adenovirus-mediated herpes simplex virus thymidine kinase/ganciclovir treatment inhibits growth of human and rat leiomyoma cells. Gynecol Obstet Invest 2007;63: 61-70.

17 Freeman SM, Abboud CN, Whartenby KA, Packman CH, Koeplin DS, Moolten FL, Abraham GN: The 'bystander effect': tumor regression when a fraction of the tumor mass is genetically modified. Cancer Res 1993;53: 5274-5283.

18 Smythe WR, Hwang HC, Elshami AA, Amin KM, Eck SL, Davidson BL, Wilson JM, Kaiser LR, Albelda SM: Treatment of experimental human mesothelioma using adenovirus transfer of the herpes simplex thymidine kinase gene. Ann Surg 1995;222: 78-86.

19 Everitt JI, Wolf DC, Howe SR, Goldsworthy TL, Walker C: Rodent model of reproductive tract leiomyomata. Clinical and pathological features. Am J Pathol 1995;146:1556-1567.

20 Houston KD, Hunter DS, Hodges LC, Walker CL: Uterine leiomyomas: mechanisms of tumorigenesis. Toxicol Pathol 2001;29:100104.

21 CookJD, Walker CL: The Eker rat: establishing a genetic paradigm linking renal cell carcinoma and uterine leiomyoma. Curr Mol Med 2004;4:813-824.

22 Al-Hendy A, Lee EJ, Wang HQ, Copland JA: Gene therapy of uterine leiomyomas: adenovirus-mediated expression of dominant negative estrogen receptor inhibits tumor growth in nude mice. Am J Obstet Gynecol 2004;191:1621-1631.

-23 Chen SH, Shine HD, Goodman JC, Grossman RG, Woo SL: Gene therapy for brain tumors: regression of experimental gliomas by adenovirus-mediated gene transfer in vivo. Proc Natl Acad Sci USA 1994;91:3054-3057.

24 Al-Hendy A, Magliocco AM, Al Tweigeri T, Braileanu G, Crellin N, Li H, Strong T, Curiel $\mathrm{D}$, Chedrese PJ: Ovarian cancer gene therapy: repeated treatment with thymidine kinase in an adenovirus vector and ganciclovir improves survival in a novel immunocompetent murine model. Am J Obstet Gynecol 2000;182:553-559.
-25 Quast MJ, Neumeister H, Ezell EL, Budelmann BU: MR microscopy of cobalt-labeled nerve cells and pathways in an invertebrate brain (Sepia officinalis, Cephalopoda). Magn Reson Med 2001;45:575-579.

26 Willis WD, Al Chaer ED, Quast MJ, Westlund $\mathrm{KN}$ : A visceral pain pathway in the dorsal column of the spinal cord. Proc Natl Acad Sci USA 1999;96:7675-7679.

27 Byrnes K, Li BD, Holm N, Li J, Okadata Y, De Benedetti A, Nedeljkovic-Kurepa A, Mathis M, Chu QD: A novel suicide gene therapy targeting the overexpression of eukaryotic initiation factor $4 \mathrm{E}$ improves survival in a rat peritoneal carcinomatosis model. Surgery 2007;142:270-275

28 Boyd W: A Textbook of Pathology, Structure and Function in Disease, ed 8. Philadelphia, Lea \& Febiger, 1979.

29 Yamada I, Tsunoda A, Noguchi Y, Komatsuzaki A, Shibuya H: Tumor volume measurements of acoustic neuromas with three-dimensional constructive interference in steady state and conventional spin-echo MR imaging. J Magn Reson Imaging 2000;12: $826-832$

30 Colgan TJ, Pendergast S, Leblanc M: The histopathology of uterine leiomyomas following treatment with gonadotropin-releasing hormone analogs. Hum Pathol 1993;24: 1073-1077.

31 Hassan MH, Salama SA, Arafa HM, Hamada FM, Al-Hendy A: Adenovirus-mediated delivery of a dominant negative estrogen receptor gene in uterine leiomyoma cells abrogates estrogen- and progesterone-regulated gene expression. J Clin Endocrinol Metab 2007; 92:3949-3957.

32 Salama SA, Jamaluddin M, Kumar R, Hassan MH, Al-Hendy A: Progesterone regulates catechol-O-methyl transferase gene expression in breast cancer cells: distinct effect of progesterone receptor isoforms. J Steroid Biochem Mol Biol 2007;107:253-261.

33 Thornberry NA: The caspase family of cysteine proteases. Br Med Bull 1997;53:478490.

34 Sbrana E, Mateo RI, Xiao SY, Popov VL, Newman PC, Tesh RB: Clinical laboratory, virologic, and pathologic changes in hamsters experimentally infected with Pirital virus (Arenaviridae): a rodent model of Lassa fever. Am J Trop Med Hyg 2006;74:10961102.

35 Alvarez RD, Barnes MN, Gomez-Navarro J, Wang M, Strong TV, Arafat W, Arani RB, Johnson MR, Roberts BL, Siegal GP, Curiel DT: A cancer gene therapy approach utilizing an anti-erbB-2 single-chain antibodyencoding adenovirus (AD21): a phase I trial. Clin Cancer Res 2000;6:3081-3087. 
>36 Schulick AH, Vassalli G, Dunn PF, Dong G, 47 Yang Y, Jooss KU, Su Q, Ertl HC, Wilson JM: Rade JJ, Zamarron C, Dichek DA: Established immunity precludes adenovirus-mediated gene transfer in rat carotid arteries: potential for immunosuppression and vector engineering to overcome barriers of immunity. J Clin Invest 1997;99:209-219.

- 37 Smith TAG, Mehaffey MG, Kayda DB, Saunders JM, Yei S, Trapnell BC, McClelland A, Kaleko M: Adenovirus-mediated expression of therapeutic plasma levels of human factorIX in mice. Nat Genet 1993;5:397-402.

-38 Harvey BG, Hackett NR, El-Sawy T, Rosengart TK, Hirschowitz EA, Lieberman MD, Lesser ML, Crystal RG: Variability of human systemic humoral immune responses to adenovirus gene transfer vectors administered to different organs. J Virol 1999;73:67296742 .

-39 Connolly KM, Bogdanffy MS: Evaluation of proliferating cell nuclear antigen (PCNA) as an endogenous marker of cell proliferation in rat liver: a dual stain comparison with 5bromo-2'-deoxyuridine. J Histochem Cytochem 1993;41:1-6.

-40 Baldin V, Lukas J, Marcote MJ, Pagano M, Draetta G: Cyclin D1 is a nuclear protein required for cell cycle progression in G1. Genes Dev 1993;7:812-821.

-41 Chang MW, Ohno T, Gordon D, Lu MM, Nabel GJ, Nabel EG, Leiden JM: Adenovirusmediated transfer of the herpes-simplex virus thymidine kinase gene inhibits vascular smooth muscle cell proliferation and neointima formation following balloon angioplasty of the rat carotid artery. Mol Med 1995;1:172-181.

42 Aghi M, Hochberg F, Breakefield XO: Prodrug activation enzymes in cancer gene therapy. J Gene Med 2000;2:148-164.

$\checkmark 43$ Spencer DM: Developments in suicide genes for preclinical and clinical applications. Curr Opin Mol Ther 2000;2:433-440.

44 Windeatt S, Southgate TD, Dewey RA, Bolognani F, Perone MJ, Larregina AT, Maleniak TC, Morris ID, Goya RG, Klatzmann D, Lowenstein PR, Castro MG: Adenovirusmediated herpes simplex virus type-1 thymidine kinase gene therapy suppresses oestrogen-induced pituitary prolactinomas. J Clin Endocrinol Metab 2000;85:1296-1305.

-45 Freytag SO, Barton KN, Brown SL, Narra V, Zhang Y, Tyson D, Nall C, Lu M, Ajlouni M, Movsas B, Kim JH: Replication-competent adenovirus-mediated suicide gene therapy with radiation in a preclinical model of pancreatic cancer. Mol Ther 2007; 15:16001606.

46 Yang Y, Ertl HC, Wilson JM: MHC class Irestricted cytotoxic $\mathrm{T}$ lymphocytes to viral antigens destroy hepatocytes in mice infected with E1-deleted recombinant adenoviruses. Immunity 1994;1:433-442. Immune responses to viral antigens versus transgene product in the elimination of recombinant adenovirus-infected hepatocytes in vivo. Gene Ther 1996;3:137-144.

48 Worgall S, Leopold PL, Wolff G, Ferris B, Van Roijen N, Crystal RG: Role of alveolar macrophages in rapid elimination of adenovirus vectors administered to the epithelial surface of the respiratory tract. Hum Gene Ther 1997;8:1675-1684

-49 Chen HH, Mack LM, Kelly R, Ontell M, Kochanek S, Clemens PR: Persistence in muscle of an adenoviral vector that lacks all viral genes. Proc Natl Acad Sci USA 1997;94: 1645-1650.

50 Hassan MH, Khatoon N, Curiel DT, Hamada FM, Arafa HM, Al-Hendy A: Toward gene fied adenovirus to human leiomyoma cells. Hum Reprod 2008;23:514-524.

51 Reed JC, Jurgensmeier JM, Matsuyama S: Bcl-2 family proteins and mitochondria. Biochim Biophys Acta 1998;1366:127-137.

52 Knudson CM, Korsmeyer SJ: Bcl-2 and Bax function independently to regulate cell death. Nat Genet 1997;16:358-363.

53 Monney L, Otter I, Olivier R, Ravn U, Mirzasaleh H, Fellay I, Poirier GG, Borner C: Bcl-2 overexpression blocks activation of the death protease CPP32/Yama/apopain. Biochem Biophys Res Commun 1996;221:340345 .

54 Nomura M, Shimizu S, Ito T, Narita M, Matsuda H, Tsujimoto Y: Apoptotic cytosol facilitates Bax translocation to mitochondria that involves cytosolic factor regulated by Bcl-2. Cancer Res 1999;59:5542-5548.

55 Wu X, Blanck A, Olovsson M, Henriksen R, Lindblom B: Expression of Bcl-2, Bcl-x, Mcl1 , Bax and Bak in human uterine leiomyomas and myometrium during the menstrual cycle and after menopause. J Steroid Biochem Mol Biol 2002;80:77-83.

56 Khurana KK, Singh SB, Tatum AH, Schulz V, Badawy SZ: Maintenance of increased Bcl-2 expression in uterine leiomyomas after GnRH agonist therapy. J Reprod Med 1999; 44:487-492.

57 Bouchard WJ, Rouleau M, Poirier GG: PARP-1, a determinant of cell survival in response to DNA damage. Exp Hematol 2003; 31:446-454.

58 Chiarugi A: Poly(ADP-ribose) polymerase: killer or conspirator? The suicide hypothesis revisited. Trends Pharmacol Sci 2002;23: 122-129.

59 Soldani C, Scovassi AI: Poly(ADP-ribose) polymerase-1 cleavage during apoptosis: an update. Apoptosis 2002;7:321-328

60 Huang SC, Tang MJ, Cheng YM, Hsu KF, Ho CL, Chou CY: Enhanced polyadenosine diphosphate-ribosylation in gonadotropin-releasing hormone agonist-treated uterine leiomyoma. J Clin Endocrinol Metab 2003; 88:5009-5016. therapy of uterine fibroids: targeting modi-
61 Shanmugathasan M, Jothy S: Apoptosis, anoikis and their relevance to the pathobiology of colon cancer. Pathol Int 2000;50:273279.

62 Dixon D, Flake GP, Moore AB, He H, Haseman JK, Risinger JI, Lancaster JM, Berchuck A, Barrett JC, Robboy SJ: Cell proliferation and apoptosis in human uterine leiomyomas and myometria. Virchows Arch 2002;441: 53-62.

63 Loy CJ, Evelyn S, Lim FK, Liu MH, Yong EL: Growth dynamics of human leiomyoma cells and inhibitory effects of the peroxisome proliferator-activated receptor-gamma ligand, pioglitazone. Mol Hum Reprod 2005;11: 561-566.

64 Kurki P, Vanderlaan M, Dolbeare F, Gray J, Tan EM: Expression of proliferating cell nuclear antigen (PCNA)/cyclin during the cell cycle. Exp Cell Res 1986;166:209-219.

65 Raper SE, Yudkoff M, Chirmule N, Gao GP, Nunes F, Haskal ZJ, Furth EE, Propert KJ, Robinson MB, Magosin S, Simoes H, Speicher L, Hughes J, Tazelaar J, Wivel NA, Wilson JM, Batshaw ML: A pilot study of in vivo liver-directed gene transfer with an adenoviral vector in partial ornithine transcarbamylase deficiency. Hum Gene Ther 2002;13:163175.

66 Worgall S, Wolff G, Falck-Pedersen E, Crystal RG: Innate immune mechanisms dominate elimination of adenoviral vectors following in vivo administration. Hum Gene Ther 1997;8:37-44.

67 Abbas AK, Murphy KM, Sher A: Functional diversity of helper T lymphocytes. Nature 1996;383:787-793.

68 Harty JT, Tvinnereim AR, White DW: CD8(+) T cell effector mechanisms in resistance to infection. Annu Rev Immunol 2000; 18:275-308

69 Radoja S, Frey AB, Vukmanovic S: T-Cell receptor signaling events triggering granule exocytosis. Crit Rev Immunol 2006;26:265290.

70 Yang Y, Li Q, Ertl HC, Wilson JM: Cellular and humoral immune responses to viral antigens create barriers to lung-directed gene therapy with recombinant adenoviruses. J Virol 1995;69:2004-2015.

71 Harvey BG, et al: Host responses and persistence of vector genome following intrabronchial administration of an E1(-)E3(-) adenovirus gene transfer vector to normal individuals. Mol Ther 2001;3:206-215.

72 Roth DA, et al: Intracoronary delivery of an adenovirus encoding fibroblast growth factor-4 in myocardial ischemia: Effect of serum antibodies and previous exposure to adenovirus. Hum Gene Ther 2006;17:230238 . 
-73 Huard J, Lochmuller H, Acsadi G, Jani A, Massie B, Karpati G: The route of administration is a major determinant of the transduction efficiency of rat tissues by adenoviral recombinants. Gene Ther 1995;2:107115.

74 Sullivan DM, Jensen TG, Taichman LB, Csaky KG: ornithine-delta-aminotransferase expression and ornithine metabolism in cultured epidermal keratinocytes: toward metabolic sink therapy for gyrate atrophy. Gene Ther 1997;4:1036-1044.

-75 Sterman DH, Recio A, Vachani A, Sun J, Cheung L, DeLong P, Amin KM, Litzky LA, Wilson JM, Kaiser LR, Albelda SM: Longterm follow-up of patients with malignant pleural mesothelioma receiving high-dose adenovirus herpes simplex thymidine kinase/ganciclovir suicide gene therapy. Clin Cancer Res 2005;11:7444-7453.

76 Ayala G, Satoh T, Li R, Shalev M, Gdor Y, Aguilar-Cordova E, Frolov A, Wheeler TM, Miles BJ, Rauen K, Teh BS, Butler EB, Thompson TC, Kadmon D: Biological response determinants in HSV-tk + ganciclovir gene therapy for prostate cancer. Mol Ther 2006;13:716-728.

-77 Nasu Y, Saika T, Ebara S, Kusaka N, Kaku H, Abarzua F, Manabe D, Thompson TC, Kumon $\mathrm{H}$ : Suicide gene therapy with adenoviral delivery of HSV-tK gene for patients with local recurrence of prostate cancer after hormonal therapy. Mol Ther 2007;15:834-840.

78 Hiltunen MO, Turunen MP, Turunen AM, Rissanen TT, Laitinen M, Kosma VM, YlaHerttuala S: Biodistribution of adenoviral vector to nontarget tissues after local in vivo gene transfer to arterial wall using intravascular and periadventitial gene delivery methods. FASEB J 2000; 14:2230-2236.

79 Othman EE, Zhu ZB, Curiel DT, Khatoon N, Salem HT, Khaifa EA, Al-Hendy A: Toward gene therapy of endometriosis; transductional and transcriptional targeting of adenoviral vectors to endometriosis cells. Am J Obstet Gynecol 2008;117:e1-e6.
80 Goodwin SC, Walker WJ: Uterine artery embolization for the treatment of uterine fibroids. Curr Opin Obstet Gynecol 1998;10: 315-320.

81 Hutchins FL Jr, Worthington-Kirsch R, Berkowitz RP: Selective uterine artery embolization as primary treatment for symptomatic leiomyomata uteri. J Am Assoc Gynecol Laparosc 1999;6:279-284.

82 Verma IM, Weitzman MD: Gene therapy: twenty-first century medicine. Annu Rev Biochem 2005;74:711-738.

83 Journal of Gene Medicine: website at http:// www.wiley.co.uk/wileychi/genmed.

84 Micheff M, Tchakaraov S, Zoubak S, Loukinov D, Botev C, Altankov I, Georgiev G, Petrov S, Meryman HT: Naked DNA and adenoviral immunizations for immunotherapy of prostate cancer: a phase I/II clinical trial. Eur Urol 2000;38:208-217.

85 Stephenson JR: Genetically modified viruses: vaccines by design. Curr Pharm Biotechnol 2001;2:47-76.

86 Stribley JM, Rehman KS, Niu H, Christman GM: Gene therapy and reproductive medicine. Fertil Steril 2002;77:645-657.

$>87$ Wivel NA, Wilson JM. Methods of gene delivery. Hematol Oncol Clin North Am 1998; 12:483-501.

-88 Nielsen LL, Lipari P, Dell J, Gurnani M, Hajian G: Adenovirus-mediated p53 gene therapy and paclitaxel have synergistic efficacy in models of human head and neck, ovarian, prostate, and breast cancer. Clin Cancer Res 1998;4:835-846.

89 Kunishige I, Samejima Y, Shiki Y, Moriyama A, Meruelo D, Saji F, Murata Y: Suicide gene therapy for human uterine adenocarcinoma cells using herpes simplex virus thymidine kinase. Gynecol Oncol 1999;72:16-25.
90 Ramondetta L, Mills GB, Burke TW, Wolf JK: Adenovirus-mediated expression of p53 or p21 in a papillary serous endometrial carcinoma cell line (SPEC-2) results in both growth inhibition and apoptotic cell death: potential application of gene therapy to endometrial cancer. Clin Cancer Res 2000;6: 278-284.

-91 Lazennec G, Alcorn JL, Katzenellenbogen BS: Adenovirus-mediated delivery of a dominant negative estrogen receptor gene abrogates estrogen-stimulated gene expression and breast cancer cell proliferation. Mol Endocrinol 1999;13:969-980.

$\checkmark 92$ Au WW, Abdou-Salama S, Al-Hendy A: Inhibition of growth of cervical cancer cells using a dominant negative estrogen receptor gene. Gynecol Oncol 2007;104:276-280.

$\checkmark 3$ Othman ER, Salama S, Ismail N, Al-Hendy A: Gene Therapy of endometriosis: adenovirus mediated expression of dominant negative estrogen receptor induces apoptosis in human endometriotic cells. Fertil Steril 2007;88:462-471.

94 Ghadami M, Salama SA, Khatoon N, Chilvers R, Nagamani M, Chedrese PJ, Al-Hendy A: Toward gene therapy of primary ovarian failure: adenovirus expressing human FSH receptor corrects the Finnish C566T mutation. Mol Hum Reprod 2008;14:9-15.

95 Saed GM, Al-Hendy A, Salama SA, Diamond MP: Adenovirus-mediated expression of cyclooxygenase-2 antisense reverse abnormal genetic profile of human adhesion fibroblasts. Fertil Steril 2008;89(suppl):14551460.

96 Cavazzana-Calvo M, Hacein-Bey S, de Saint Basile G, Gross F, Yvon E, Nusbaum P, et al: Gene therapy of human severe combined immunodeficiency (SCID)-X1 disease. Science 2000;288:669-672. 